\title{
COMPARING LABORATORY AND WELL LOG PETROPHYSICAL PROPERTIES IN AN ALBIAN CARBONATE RESERVOIR OF SOUTHEASTERN BRAZIL
}

\author{
Abel Carrasquilla, Christiane de Abreu, Paula Almeida and Fernanda Tavares
}

\begin{abstract}
This study evaluated the petrophysical properties of an Albian carbonate reservoir, positioned in the post-salt layer, located in the Campos Basin, Southeastern Brazil. Geological information, geophysical well logs, and, laboratory experimental data with samples were used to do this. Based on density, neutron and sonic logs, different approaches were proposed to determine the porosity. The Nuclear Magnetic Resonance log was also used to evaluate both porosity and permeability, this last with various methods. In the sequence, all these estimates were compared between them and the laboratory experimental data. The results show that, an estimation of the porosity is much easier than an evaluation of the permeability. This is demonstrated when the porosity is determined, with a good fit, in a multiple linear regression, whereas, the permeability is only evaluated, with good fit, in a multiple polynomial regression.
\end{abstract}

Keywords: well logging, petrophysics, carbonate reservoir, Albian.

RESUMO. Este estudo petrofísico caracterizou um reservatório carbonático localizado na camada pós-sal da Bacia de Campos, utilizando informações geológicas, perfis geofísicos de poços e dados experimentais de laboratório com amostras. Com base nos perfis densidade, neutrônico e sônico, diferentes abordagens foram propostas para determinar a porosidade. Da mesma forma, também foi utilizada a Ressonância Magnética Nuclear para avaliar a porosidade e a permeabilidade baseando-se em diferentes métodos. Posteriormente, todos esses parâmetros foram comparados entre si e com dados experimentais de laboratório. Os resultados mostram que estimar a porosidade é muito mais simples do que avaliar a permeabilidade, porque a porosidade é bem determinada com bom ajuste em uma regressão linear múltipla e, para a permeabilidade, um bom ajuste é alcançado apenas com uma regressão polinomial múltipla.

Palavras-chave: perfis de poços, petrofísica, reservatório carbonático, Albiano.

Corresponding author: Abel Carrasquilla

Universidade Estadual do Norte Fluminense Darcy Ribeiro, Laboratório de Engenharia e Exploração de Petróleo, LENEP/UENF, Av. Brennand S/N, Imboacica, Cx. Postal 119562, 27925-535, Macaé, RJ, Brazil. Phone/Fax: +55 (22) 2765-6565 - E-mails: abel@lenep.uenf.br, chrisrabreu@gmail.com, paula-almeida@hotmail.com.br, fernandagtavarez@gmail.com 


\section{INTRODUCTION}

This work was performed in a carbonate reservoir of Campos Basin, which is located along the continental shelf of Southeast Brazil. It is the most productive oil basin along the Brazilian continental margin, accounting for more than $46 \%$ of national production, based on data from 2018 (Fig. 1). The Albian carbonate reservoirs of Quissamã Formation, with typical porosity and permeability of $25 \%$ and $25 \mathrm{mD}$, respectively, are oil productive within the basin (Bruhn et al., 2003). The sedimentation of this carbonate, started in the drift phase, at the beginning of Albian with marine deposition (Fig. 2a). The depositional model, of this oilfield, is related to a carbonate platform and, according to Okubo et al. (2015), is characterized by sedimentation in high, moderate and low energy environments (Fig. 2b). These energy levels are related as oolitic and oncolytic grainstones, oolitic peloidal grainstones and oncolitic bioclastic packstones and, peloidal bioclastic packstones and wackestones, respectively. Thus, the reservoir has three zones being called, from the youngest to the oldest, as packstone, grainstone and, cemented grainstone. The grainstone is considered the reservoi, because it has the higher values of porosity and permeability.

To characterize the petrophysical properties of carbonate reservoirs, as porosity and permeability, the interpretation of logs and the evaluation of samples of rocks in the laboratory are the most used methods, in order to discover the affinity between these parameters in this type of reservoirs. The resolution and spatial coverage of these two methodologies, combined with the measured and estimated parameters, produce different scales to obtain lithological and structural information in subsurface (Aguilera \& Aguilera, 2001).

Rock porosity $\phi$ is evaluated directly, in laboratory experiments, using plugs, cores and rock samples. In wells, on the other hand, is measured, directly, using neutron porosity log (NPHI). It can also be obtained by indirect measurements through sonic (DT), density (RHOB), nuclear magnetic resonance (NMR) and electromagnetic propagation (EPT) well logs. $\phi$ estimate from logs is not easy and immediate task, since, usually, a single log is unable to provide a reliable estimate, because they are dependent on various interaction forms between lithology, fluid type, porous geometry and physical properties (Abreu, 2015). Therefore, it is common to use more than one log, aiming to reach a better $\phi$ estimation (Alberty, 1994).

In the case of permeability this parameter is evaluated by direct measurements in laboratory or by drill stem tests. The evaluations, in the first, are made in rock samples. The second is, although, a procedure for isolating and testing the pressure, permeability and productive capacity of a geological formation during the drilling of a well. Both are, normally, only available from a few wells in an oilfield. But almost all wells are logged and, to derive $k$, from logs, many approaches exist. Thus, $k$ is estimated by the NMR log, using a combination of theoretical and core-based models. This shows that, when the $\phi$ and the pore-size raise, k enhances, too. With this log, $k$ is calculated from the spectral-porosity measurements, using different relationships created from these models (Shenawi et al., 2007).

This study explores, therefore, the virtues of well logs interpretation, added to the rock samples laboratory evaluation and, supported by the geological information. The work uses a dataset, from a Campos Basin carbonate reservoir, to evaluate the reliability of $\phi$ and $\mathrm{k}$ estimates. It was adopted, to achieve these objectives, the following structure: interpretation of well logs, estimates $\phi$ and $k$ using empirical equations and multiple regressions, compares these estimates with laboratory data, analysis of the quality of the adjustment of these estimates with the real data and, conclusions reached by the adoption of this methodology (see Fig. 3).

\section{METHODOLOGY}

To develop this work, the initial data set of caliper (CAL), gamma ray (GR), RHOB, resistivity (RT), NPHI and DT basic logs, along with the NMR log, were plotted and analysed. The analysis includes the processing of the data, which consisted of its preparation to eliminate the anomalous data or outliers. Hereafter, the basic logs were used to characterize the reservoir, meantime, the laboratory data, with porosity and permeability, was used to divide the reservoir in zones. The organization, plotting and interpretation of the log data were performed using Interactive Petrophysics software (LR Senergy, 2018).

The $\phi$ and $k$, continuing, were obtained from the empirical models with the well logs. In order to estimate $\phi$, we used the geophysical well logs of RHOB (Schlumberger, 2013), NPHI (Scott el al., 1994), DT (Wyllie et al., 1956), NMR (Coates et al., 1999) and, a combination of all of them through a multiple linear regression. Thereafter, different $\phi$ values were computed and plotted, using the equations shown in the Table 1, as also, compared with $\phi$ experimental data. Then, a multiple linear regression, that includes all the $\phi$ approaches mentioned above, was produced to accomplish a better fit with the laboratory data (Abreu, 2015).

For $k$, the procedure was very similar to $\phi$. First, different $k$ values were computed and plotted using the equations presented 


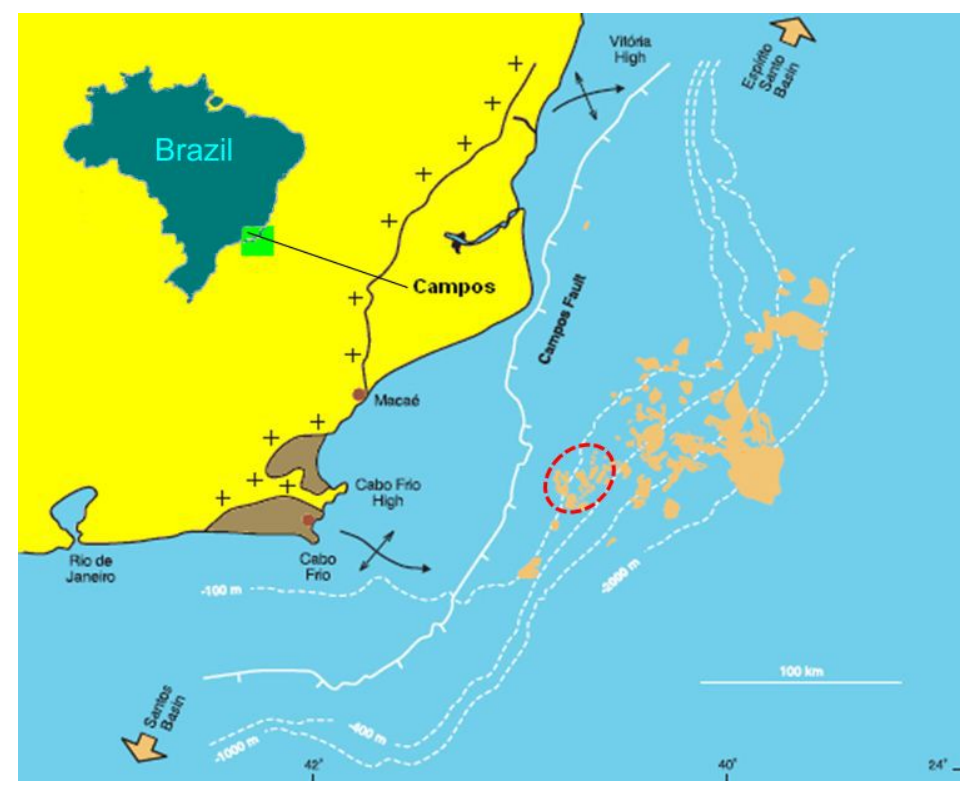

Figure 1 - Campos Basin in Southeast Brazil and the approximate position of the carbonate reservoir of the Albian in the dashed ellipse (modified from Bruhn et al., 2003).

Table 1 - Summary of porosity estimates from logs.

\begin{tabular}{|l|l|c|l|}
\hline Logs & Required data & Formula & Reference \\
\hline Density & $\rho_{\mathrm{MA}}$ and $\rho_{F L}$, matrix and fluid densities & $\phi_{R H O B}=\frac{\rho_{\log }-\rho_{M A}}{\rho_{F L}-\rho_{M A}}$ & Schlumberger (2013) \\
\hline Neutron & Calibration of the tool with known samples & $\phi_{N P H I}$ & Scott et al. (1994) \\
\hline Sonic & $\mathrm{DT}_{M A}$ and $\mathrm{DT}_{F L}$, matrix and fluid transit times & $\phi_{D T}=\frac{D T_{\log }-D T_{M A}}{\Delta t_{F L}-\Delta t_{m a}}$ & Wyllie et al. (1956) \\
\hline NMR & Hydrogen index using NMR relaxation times $\mathrm{T}_{1}$ and $\mathrm{T}_{2}$ & $\phi_{N M R}$ & Coates et al. (1999) \\
\hline Regression & $\phi_{R H O B}+\phi_{N P H I}+\phi_{D T}+\phi_{N M R}$ & $\begin{array}{c}\phi_{R E G R E S S I O N}=-0.007+0.407 \phi_{R H O B}+ \\
0.191 \phi_{N P H I}+0.051 f_{D T}+0.303 \phi_{N M R}\end{array}$ & Abreu (2015) \\
\hline
\end{tabular}

in the Table 2, as also, compared with $\mathrm{k}$ laboratory data. Four different approaches were utilized (Table 2), which are the empirical formulas of Timur (1968), Coates et al. (1999), Schlumberger (2013) and a multiple polynomial regression, which considers all previous estimates (Tavares, 2015). A multiple polynomial regression, which includes all the above approaches, was done to better fit the laboratory data. Finally, considering all the results, the conclusions were reached.

\section{RESULTS}

Figure 4a shows the masked depth (track 2), due to the secrecy of the data. The basic GR (track 1), RT (track 10) and NPHI RHOB (track 11) logs, which were used in this work to characterize the reservoir. This figure shows, the lithological sample analysis, in tracks: 3-cores, 4-texture, 5-granulometry, 6-oil presence, 7-facies, 8-facies and, 9-petrophysical units. The zones, with packstones, grainstones and cemented grainstones, appear clearly distinguished. Finally, the experimental measurements of porosity and permeability, in laboratory, are shown in tracks 12 and 13, respectively (Carrasquilla et al., 2012).

The presence of $U$, in marl, is shown by values of 75 $150^{\circ} \mathrm{API}$, in the GR log, between 5 to $20 \mathrm{~m}$ depth (track 2). The carbonate has a value of $30^{\circ} \mathrm{API}$ between 21 and $49 \mathrm{~m}$. CAL log shows, on the other hand, between the depths of 20 and $40 \mathrm{~m}$, a narrowing, 12 to 9 inches, and enlargement, up to 15 inches, precisely where the reservoir is located (Fig. 4b). After $40 \mathrm{~m}$, the well continued to be drilled with a 10 inches diameter. Both resistivity logs, shallow and deep, called RXO and RT, respectively, have low values at 25 depth and, they are overlapping, what characterizes an impermeable formation, as 
(a)

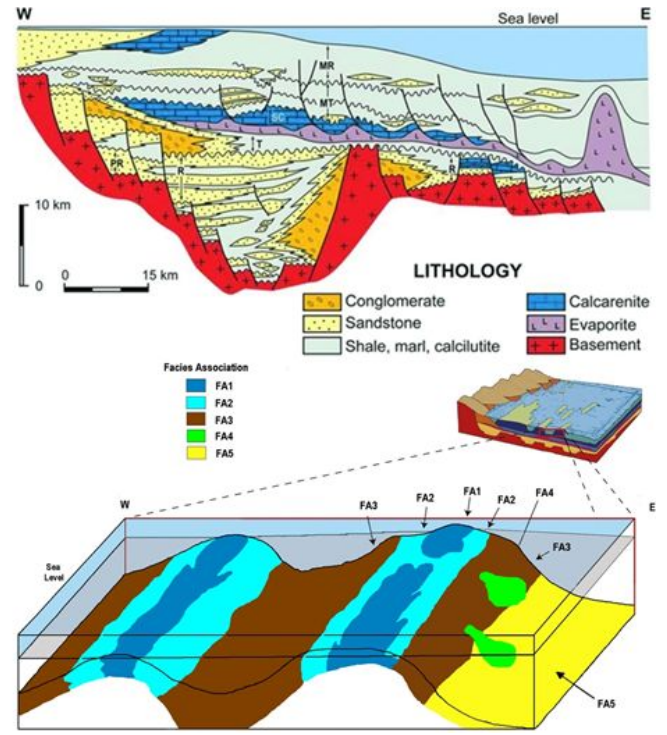

Figure 2 - (a) Generalized geological section for the Eastern Brazilian continental margin basins, showing the main mega sequences: PR, pre-rift (which does not occur in the Campos Basin); R, rift; T, transitional (which includes the evaporate section); SC, shallow carbonate; MT, marine transgressive; MR, marine regressive (modified from Bruhn et al., 2003). (b) Inferred depositional model for the carbonate platform in the Campos Basin during the Albian Age. The Facies Association (FA) are: $F A 1$ is oncolitic and oolytic grainstones, FA2 is oncolitic peloidal grainstones and oncolitic bioclastic packstones, FA3 is wackestones and peloidal bioclastic packstones, FA4 is bioclastic packstones and oolitic wackestones/packstones and, FA5 is pithonelid wackestones. FWWB is Fair Weather Wave Base (modified from Okubo et al., 2015).

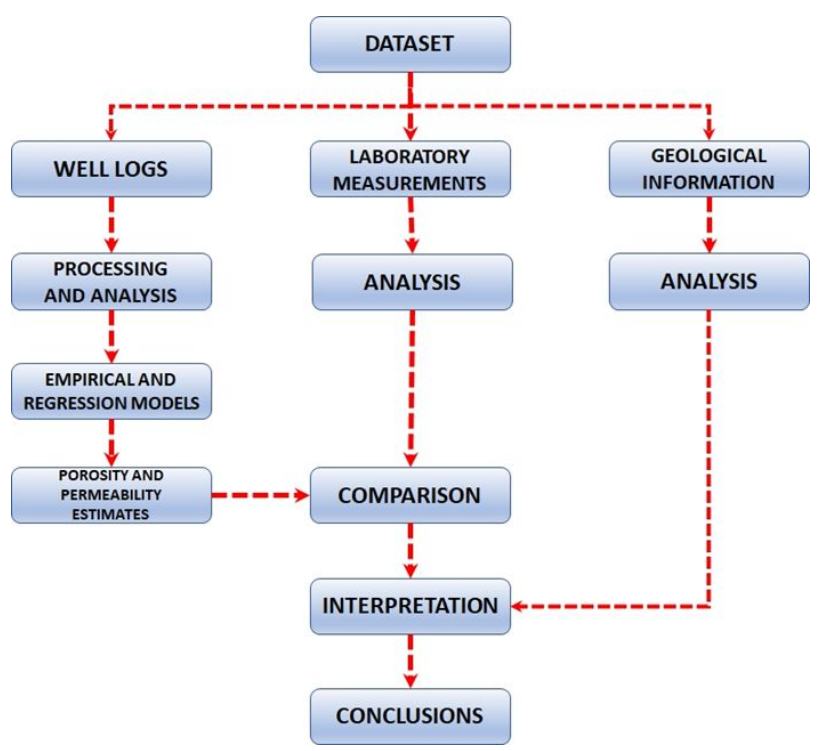

Figure $\mathbf{3}$ - Workflow with a sequence of steps required in the work. 

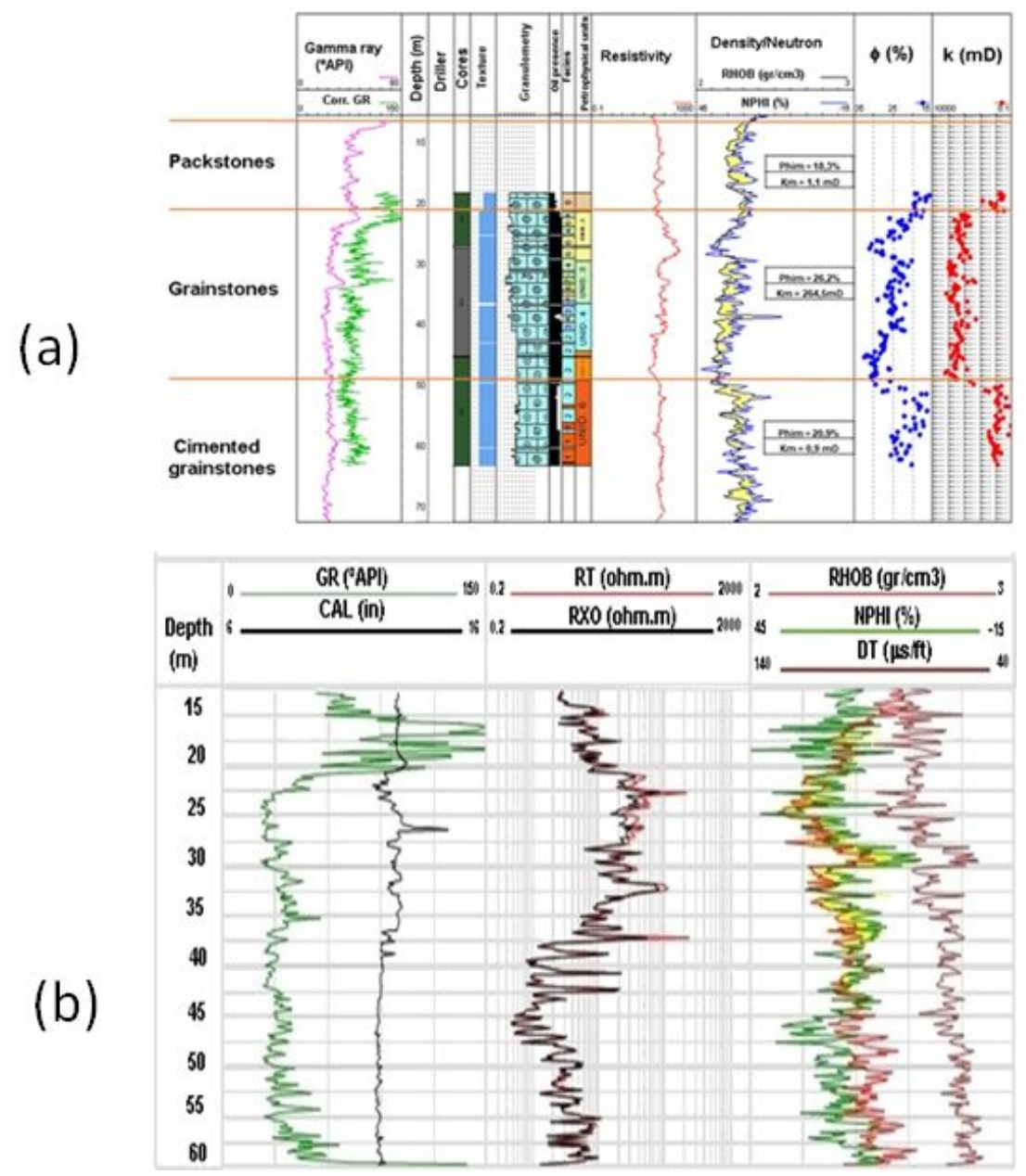

Figure 4 - (a) Campos Basin well. Tracks: 1-GR, 2-depth, 3-driller (no information), 4-cores, 5-texture, 6-granulometry, 7-oil presence, 8-facies, 9-petrophysical units, 10-RT, 11- NPHI and RHOB, 12-porosity and 13-permeability experimental data. (b) Campos Basin well, basic logs. Tracks: 1- GR and CAL, 2- RT and RXO, 4RHOB, NPHI and DT (modified from Nocchi et al., 2012).

marl (track 3, Fig. 4b). Between 25 and $30 \mathrm{~m}$, this difference is most prominent with values up to $2000 \mathrm{ohm} . \mathrm{m}$, which characterizes the presence of hydrocarbons in a permeable formation. The contact, between oil and water, is marked by a decrease in the resistivity at depth $40 \mathrm{~m}$ and, hence, the resistive logs have low values up to $1.0 \mathrm{ohm}$.m which shows the presence of brine. NPHI and RHOB logs are, separated, at some depths, and, at others, crossed. This indicates the presence of gas, due to the increase in NPHI apparent porosity (24 to $32 \%$ ) and a decrease in the RHOB $\log (2.4 \text { to } 2.2 \mathrm{~g} / \mathrm{cm})^{3}$. In addition, the crossing of these logs (yellow shadow) shows the limits of the reservoir, which provides a qualitative prediction of the upper and the bottom parts between 20 and $50 \mathrm{~m}$ (track 11, Fig. 4a and track 4, Fig. 4b), and DT log (track 4, Fig. 4b) shows a decrease in slowness (increase in speed) from 80 to $60 \mu \mathrm{s} / \mathrm{tt}$, which is common when compaction increases with depth (Nocchi et al., 2012).

Figure 5 shows, track 4, the $\phi$ laboratory measurements $\phi_{\text {LAB }}$ (blue dots), together with the $\phi$ calculated, using the equations shown in Table 1 . They are NMR multiple linear regression ( $\phi_{\text {NMR_MLR, }}$, red curve) and NMR total $\phi\left(\phi_{\text {T_NMR }}\right.$, black curve). Both $\phi_{\text {T_NMR }}$ and $\phi_{\text {NMR_MLR, visually, not fit well }}$ $\phi_{\llcorner A B}$, appearing above or below of the experimental data. The transversal relaxation time T2 cut-off (T2_ CuT-off) was used to generate $\phi_{\text {T_NMR }}$ (track 5), using a standard value of $100 \mathrm{~ms}$ for carbonates (red straight), while geometrical mean - T2_GM 


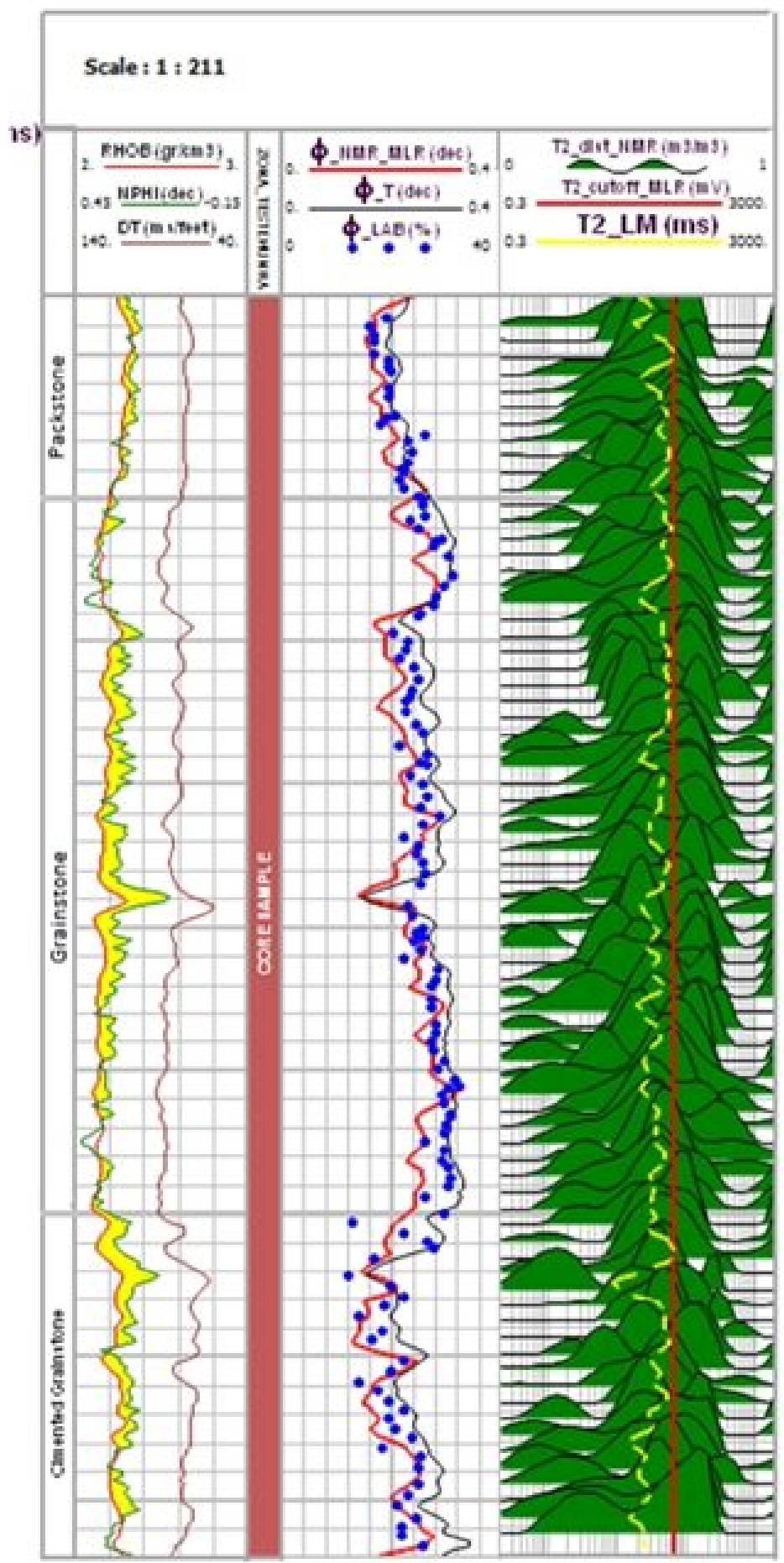

Figure 5 - Tracks: 1- basic logs RHOB, NPHI and DT, 4- Porosity estimates, 5- NMR T2_DIST,

T2_CUT-0FF and T2_LM cut-offs (modified from Tavares, 2015). 

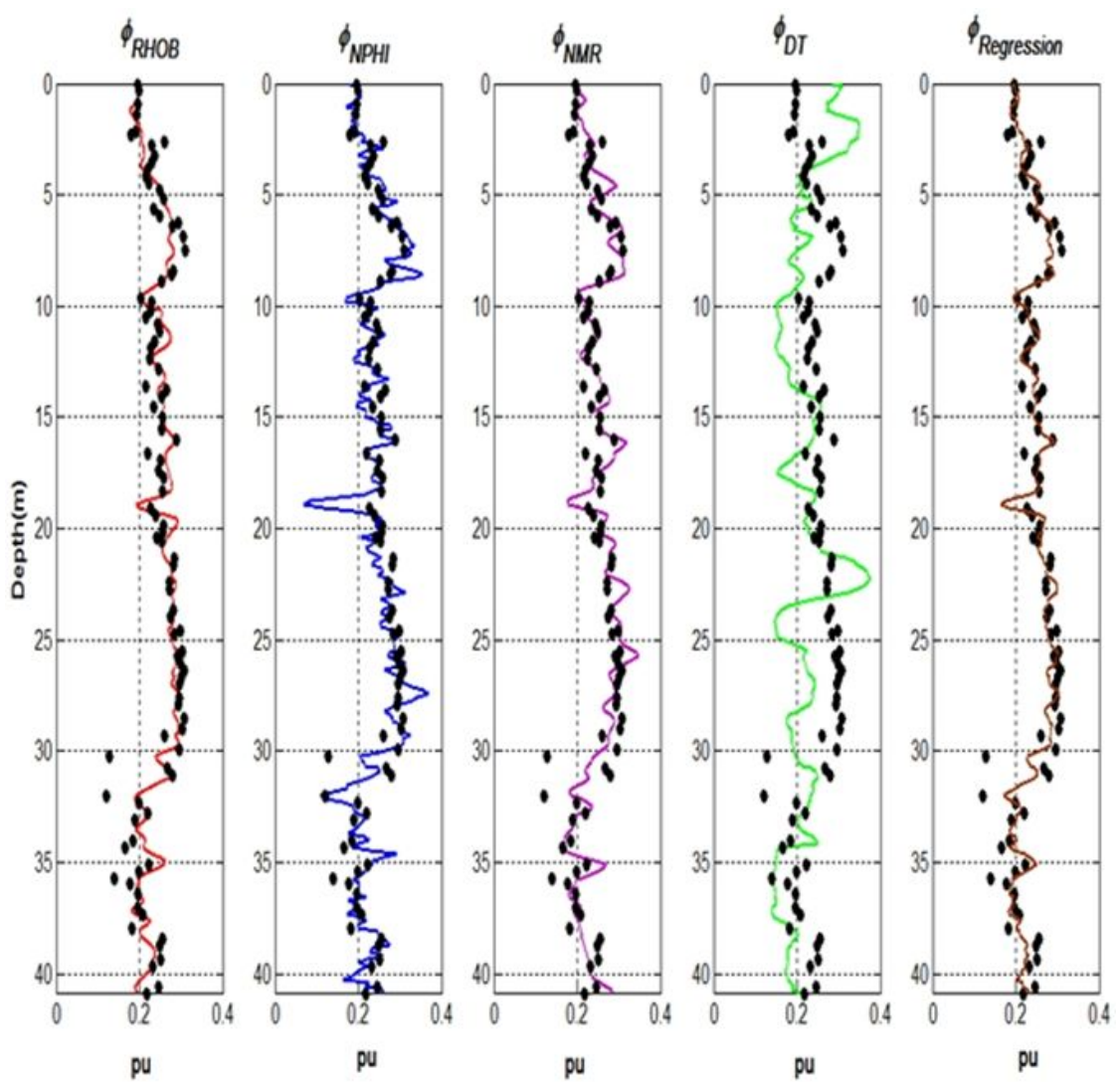

Figure 6 - Porosity estimates from RHOB (track 1), NPHI (track2), NMR (track 3) and DT (track 4) logs and regression estimate (track 5) (modified from Tavares, 2015).

(yellow curve) was used to generate $\phi_{\text {NMR_MLR, using the mean }}$ geometric cut-off the T2 distribution (T2_dist). The NMR total porosity $\left(\phi_{T_{-} \mathrm{NMR}}\right)$ is shifted to the right of $\phi_{\text {LAB }}$, while $\phi_{\text {NMR_MLR, }}$ to the left (track 4). This can be related to the chosen cut-off in the T2_DIST, which can be selected between the mobile fluid (FFI, also called BVM, hydrocarbons plus water), water and immovable fluids (BVI) and clay-bound-water (CBW). The approaches follow, however, the shape of the experimental $\phi$. Because of this bad estimate of this parameter, we decided to perform an assessment that considers the $\phi_{\mathrm{RHOB}}, \phi_{\mathrm{NPH}}, \phi_{\mathrm{NMR}}$ and $\phi_{\mathrm{DT}}$ approaches through a multiple linear regression ( $\phi_{\text {REGRESSION }}$ ). Figure 6 shows, between tracks 1 to 4 , various methods to $\phi$ estimate ( $\phi_{\mathrm{RHOB}}, \phi_{\mathrm{NPH}}, \phi_{\mathrm{NMR}}$ and $\phi_{\text {DT }}$ ), and $\phi_{\text {REGRESSION }}$ in the track 5 , which uses a combination of these four previous $\phi$ as shown in Table 1. A better adjustment, of $\phi_{\text {LAB }}$ values, is achieved with $\phi_{\text {REGRESSION }}$, having $R^{2}>80 \%$.

Figure 7 (track 5) shows, regarding $k$, the laboratory measurements $k_{\mathrm{LAB}}$ (blue dots). At the same time, we observed $k_{\text {COATES }}$ (black curve), $k_{S D R}$ (green curve) and $k_{\text {TIMUR }}$ (red curve), all calculated with the equations of the Table 2 . $k$ is obtained using
Coates approach has the form $k_{\text {COATES }}=\left(\phi_{T} / \mathrm{C}\right)^{\mathrm{a}}(\mathrm{BVM} / \mathrm{BV})^{\mathrm{b}}$, where $\phi_{\mathrm{T}}=\phi_{\mathrm{NMR}}$, and, $\mathrm{a}=4, \mathrm{~b}=2$ and $6<\mathrm{c}<15$ are empirical constants (Coates et al., 1999). Timur approach was used to estimate $k_{\text {TIMUR }}=\mathrm{a}\left(\phi_{T^{b}}{ }^{\mathrm{b}}\right) / S_{\text {WIRR }}$ (red curve), where $\phi_{T}=\phi_{\text {NPHI }}, S_{\text {WIRR }}=$ BVI I $(\mathrm{BVI}+\mathrm{BVM})$ is the irreducible water saturation and, $\mathrm{a}=10$, $\mathrm{b}=4.4$ and $\mathrm{c}=2$ (Timur, 1968). Schlumberger Doll Research (SDR) approach was used to estimate $\mathrm{k}_{\mathrm{SDR}}=\mathrm{b} \phi_{T}^{m} T_{2 \mathrm{GM}}^{b}$, where $\phi_{\mathrm{T}}=\phi_{\mathrm{NMR}}$, and, $T_{2 G M}$ is the T2 distribution geometric mean cut-off. The empirical variables $b=4$ and $m=4$ are dependent on the geological formation, in the equation (Schlumberger, 2013).

The permeabilities SDR $\left(k_{S D R}\right)$ and Timur $\left(k_{T M U R}\right)$ have similar behavior across the reservoir, overlapping at some depths. $k_{\text {COATES }}$ shows, instead, a marked deviation of the laboratory data, in some depths. In a general way, all the $k$ estimates maintain a similar distribution pattern, where the worst values appear in the packstones and cemented grainstones, while the best fit to experimental data is in the sector of the grainstones. $\mathrm{k}_{\mathrm{SDR}}$ and $\mathrm{k}_{\text {TIMUR }}$ have, although, a better fit than $\mathrm{k}_{\text {COATES }}$, as shown in tracks 1 to 3 of Figure 8, but all far from a good fit with $k_{\text {LAB }}$. A regression 


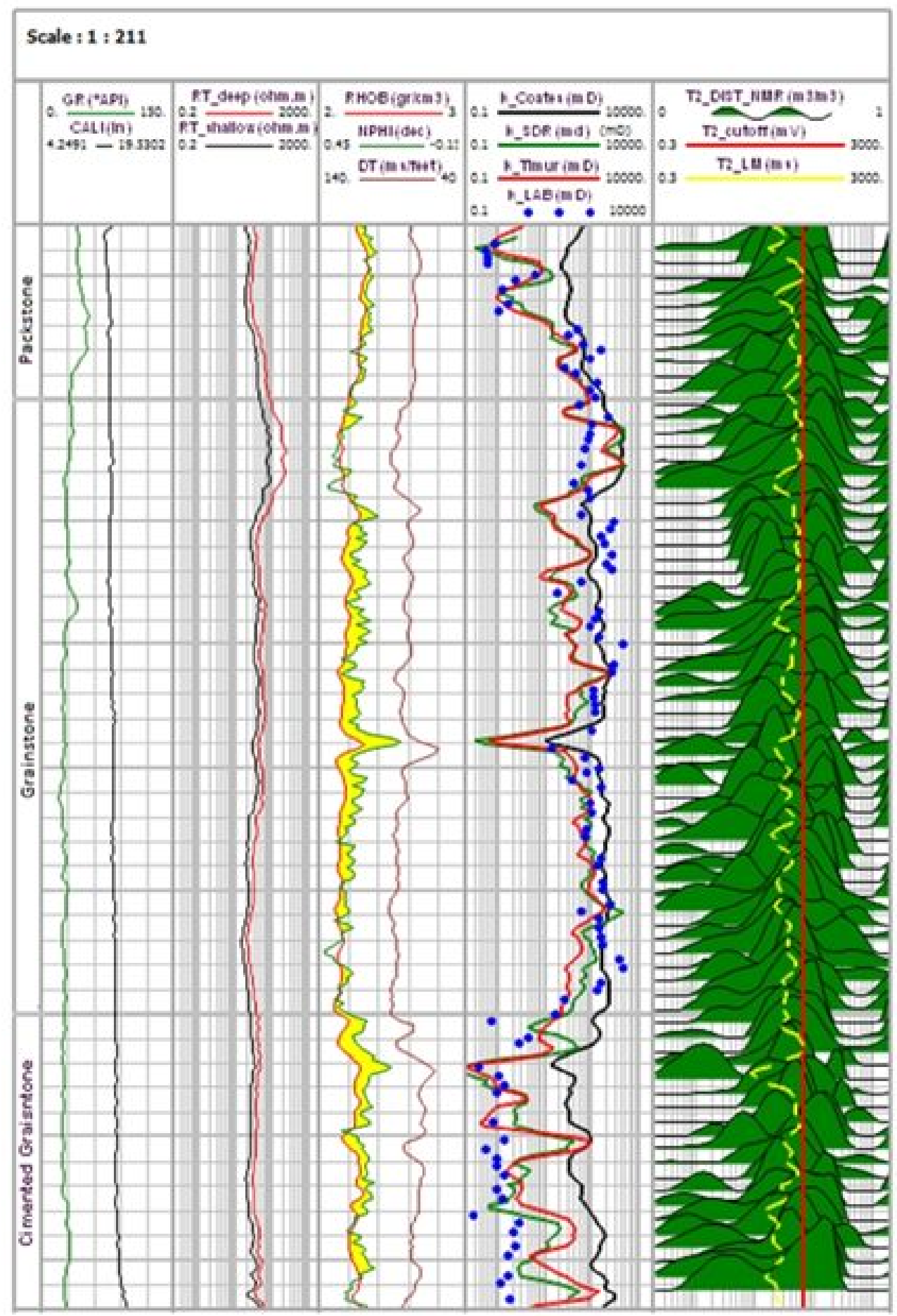

Figure 7 - Gamma ray, caliper, resistivity, RHOB, NPHI and DT logs, together with permeability estimates and NMR - T2 distribution (modified from Tavares, 2015). 

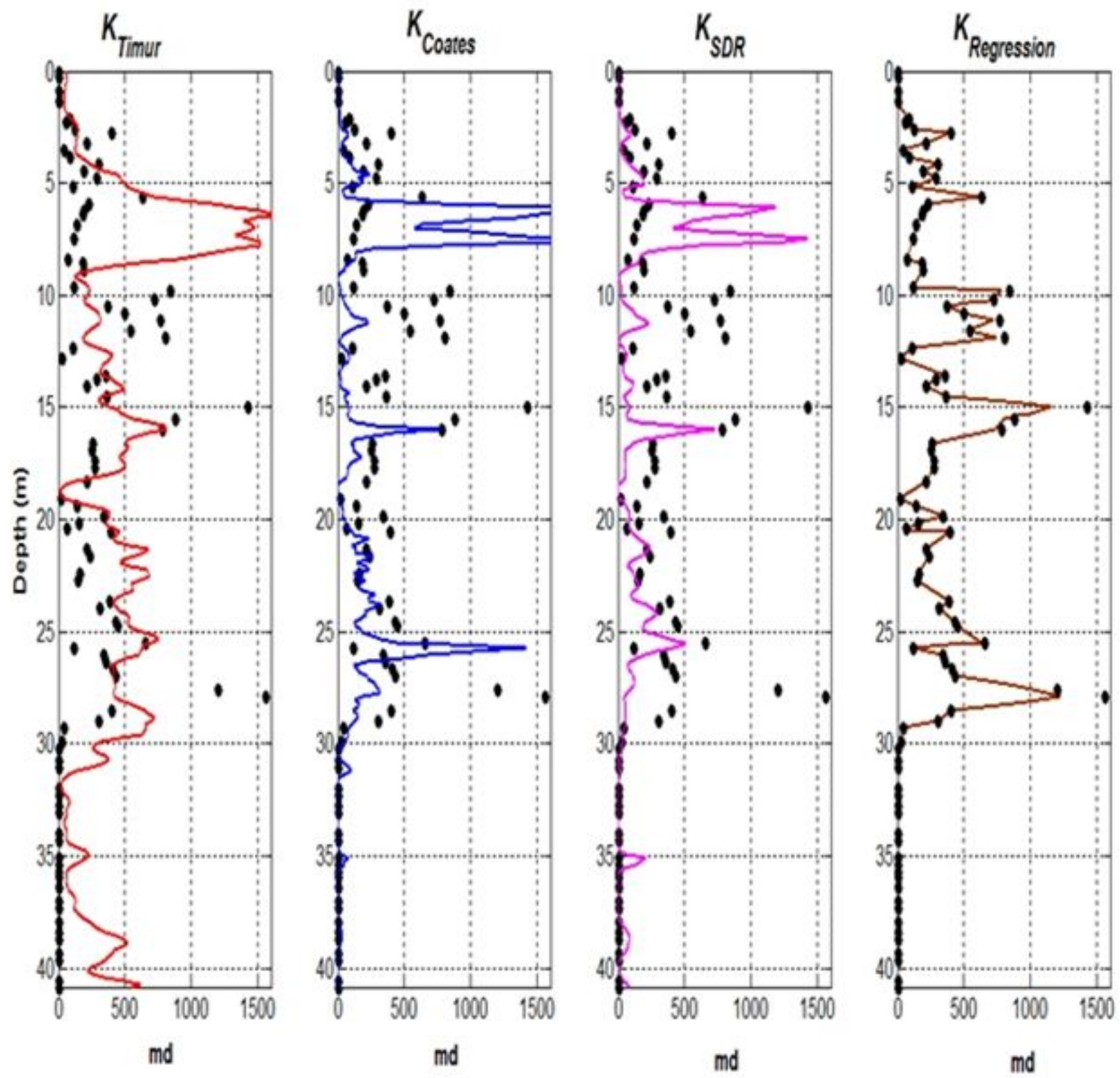

Figure 8 - Permeability estimates using Timur (track 1), Coates (track 2), SDR (track 3) and Multiple Polynomial Regression (track 4) approaches (modified from Tavares, 2015). 
was tried, because of that, using, as input, the previous estimates. A simple linear regression, by doing this, was found, but it had a bad fit (not shown in the article). A multiple regression ( $\mathrm{k}_{\text {REGRESSION }}$ ), with polynomials, adjusts well $\mathrm{K}_{\text {LAB }}$, as shown in track 4 with $R^{2}>90 \%$.

All these results agree with several works related to the characterization of Albian carbonates from Campos Basin, such as Nocchi (2012), Almeida (2015), Lichotti (2016), Silva (2016), Gomes (2017), Mureb (2018) and Al-Lahham (2018).

\section{CONCLUSIONS}

This study used a data set from an Albian carbonate reservoir in the Campos Basin. The work utilized, to do this, a joint interpretation of logs, laboratory measurements and, geological data. The aim was to assess petrophysical parameters and, to determine the reliability of porosity and permeability estimates. The reservoir was divided, initially, in packstone, grainstone and, cemented grainstone zones. The split was based on the stratigraphic control, which was established from laboratory tests and, log data. The grainstone zone was considered, thus, with the best petrophysical properties, because it has the highest values of porosity and permeability. In the development of work, the dataset of basic logs CAL, GR, RHOB, RT, NPHI and DT, along with the NMR log, were plotted, analyzed and interpreted. The following, porosities were calculated with empirical equations, plotted and compared with laboratory values. Then, a multiple linear regression, that includes all the approaches of porosities, was made with $R^{2}>80 \%$. The work indicated that, among porosity evaluations, the sonic showed the worst of all, as well as, the multiple linear regression was the better. This last combines the porosities estimates of the density, neutronic, sonic and, magnetic nuclear resonance logs. Nuclear magnetic resonance permeability, on the other hand, showed a wide variation in relation to the T2 distribution cut-offs, which is more related to the porosity input. In addition, the permeability estimates of the Timur, Coates and Schlumberger Doll Research approaches did not show a good fit with the laboratory permeability. When comparing the adjustments, the Timur estimates was the best and, the Coates one the worst. This result can be attributed to a better tuning made to the parameters of the Timur empirical method, what takes a close estimate of true permeability. A combination of the three estimates, however, proved to have a good fit with a multiple polynomial regression, with $R^{2}>$ $90 \%$. This shows that, magnetic nuclear resonance, is very good for estimating the total porosity of the reservoirs. Their estimates must be accepted with restrictions, especially, when used in a quantitative assessment of permeability, because it is predominantly qualitative and, needs calibration with laboratory data. The methodology used in this work, therefore, showed a practical and efficient workflow to evaluate carbonate reservoirs, with the nuclear magnetic resonance log contributing, positively, for a good petrophysical characterization. Finally, this work has shown that, in a general way, porosity estimate is much simpler than permeability, because as it is determined with good fit in a multiple linear regression and, a worthy fit for permeability is achieved only with a multiple polynomial regression, with a second-degree polynomial.

\section{ACKNOWLEDGEMENTS}

The authors thank Petrobras for supporting the research project and ANP for the release of the dataset. In addition, thanks to UENF - LENEP for the facilities, LR Senergy (2018) for the academic license of Interactive Petrophysics software and reviewers for their valuable suggestions.

\section{REFERENCES}

ABREU C. 2015. Estimation and classification of the porosity using geophysical logs applied to the Albian carbonate of the Campos Basin. Master Thesis, UENF, Macaé - RJ, Brazil, 100 pp. [in Portuguese].

AGUILERA R \& AGUILERA M. 2001. The integration of capillary pressures and Pickett plots for determination of flow units and reservoir containers. In: SPE Annual Technical Conference and Exhibition. New Orleans, Paper 71725.

ALBERTY M. 1994. Standard interpretation; part 4-wireline methods. In: MORTON-THOMPSON D \& WOODS AM (Eds.). Development Geology Reference Manual. AAPG Methods in Exploration Series, 10: 180-185.

AL-LAHHAM M. 2018. Permeability of carbonate reservoirs of the lower Albian determined with artificial intelligence techniques. Master Thesis, LENEP/UENF, Macaé - RJ, Brazil, 145 pp. [in Portuguese].

ALMEIDA P. 2015. Integration of geological attributes and petrophysical properties derived from the interpretation of well logs in the study of the dynamic behavior of a carbonate reservoir in the Campos Basin. Master Thesis, UENF/CCT/LENEP, Macaé - RJ, Brazil, 115 pp. [in Portuguese].

BRUHN C, GOMES J, LUCCHESE JR C \& JOHANN P. 2003. Campos Basin: reservoir characterization and management - historical overview and future challenges. In: Offshore Technology Conference. Houston. Paper OTC 15220.

CARRASQUILLA A, NOCCHI G, BRIONES V, TORRES M, FRANCO FILHO N, SCHUAB F \& SANCHEZ P. 2012. Petrophysical studies in the characterization of carbonate reservoirs in Campos Basin - Brazil. In: AAPG/SPE/SEG Hedberg Research Conference, Fundamental Controls on Flow in Carbonates. Annals, Saint Cyr sur Mer, France. 
COATES G, XIAO L \& PRAMMER MG. 1999. NMR logging: principles and applications. Halliburton Energy Services, Gulf Professional Publishing, Houston, 253 pp.

GOMES R. 2017. Comparative study of the permeability estimates of a Campos Basin carbonate reservoir obtained through machine learning methods. Master Thesis, UENF/CCT/LENEP, Macaé - RJ, Brazil, 93 pp. [in Portuguese].

LICHOTTI H. 2016. Characterization of a carbonate reservoir of the Campos Basin from the integration of geological attributes, petrophysical properties and well log studies. Master Thesis, UENF/CCT/LENEP, Macaé - RJ, Brazil, 122 pp. [in Portuguese].

LR SENERGY. 2018. Interactive Petrophysics v4.3, Online user's manual. Available on: <http://www.Ir-senergy.com/software/ipl>. Access on: December 7, 2018.

MUREB P. 2018. Use of multivariate statistics to estimate the permeability of a carbonate reservoir in the Campos Basin. Master Thesis, UENF/CCT/LENEP, Macaé - RJ, Brazil, 68 pp. [in Portuguese].

NOCCHI G. 2012. Carbonate reservoir evaluation of the fields through integration between petrophysical laboratory and well logs data. Master Thesis, UENF/CCT/LENEP, Macaé - RJ, Brazil, 112 pp. [in Portuguese].

NOCCHI G, CARRASQUILLA A, FRANCO FILHO N \& SCHUAB F. 2012. Evaluation of the carbonate reservoir of the field basin integrating laboratory data with well logs. In: V Brazilian Symposium on Geophysics. Sociedade Brasileira de Geofísica (SBGf), Salvador - BA, Brazil. [in Portuguese].

OKUBO J, LYKAWKA R, WARREN L, FAVORETO J \& DIAS-BRITO D. 2015. Depositional, diagenetic and stratigraphic aspects of Macaé Group carbonates (Albian): example from an oilfield from Campos Basin. Brazilian Journal of Geology, 45(2): 243-258.

SCOTT H, WRAIGHT P, THORNTON J, OLESEN J, HERTZOG R, McKEON D, DASGUPTA T \& ALBERTIN I. 1994. Response of a multidetector pulsed neutron porosity tool. In: Transaction of the SPWLA 35th Annual Logging Symposium. Tulsa, Oklahoma, USA, paper J.

SCHLUMBERGER. 2013. Log interpretation charts. Educational Services. USA, $306 \mathrm{pp}$.

SHENAWI H, WHITE J, ELRAFIE E \& KILANY K. 2007. Permeability and water saturation distribution by lithology facies and hydraulic units: a reservoir simulation case study. In: $15^{\text {th }}$ Middle East Oil \& Gas Show and Conference. Society of Petroleum Engineers (SPE). Manama, Bahrain. Paper SPE 105273.

SILVA R. 2016. Petrophysical characterization of Albian carbonate reservoir from well logs and laboratory measurements. Master Thesis, UENF/CCT/LENEP, Macaé - RJ, Brazil, 156 pp. [in Portuguese].

TAVARES F. 2015. Comparative study of the different estimates of permeability from well logs in carbonate reservoirs. Graduate thesis, UENF, Macaé - RJ, Brazil, 98 pp. [in Portuguese].

TIMUR A. 1968. An investigation of permeability, porosity, and residual water saturation relationships for sandstone reservoirs. The Log Analyst, 9(4): SPWLA-1968-vIXn4a2.

WYLLIE MRJ, GREGORY AR \& GARDNER LW. 1956. Elastic wave velocities in heterogeneous and porous media. Geophysics, 21(1): 41-70.

Recebido em 18 de março de 2019 / Aceito em 10 de janeiro de 2020

Received on March 18, 2019 / Accepted on January 10, 2020 